\title{
THE STUDY ABOUT ELECTRIC VEHICLES IN LITHUANIA
}

\author{
Jurgita Ginavičienè \\ Vilnius College of Technologies and Design, Lithuania \\ Indrè Sprogytè \\ Vilnius College of Technologies and Design, Lithuania
}

\begin{abstract}
Electric cars are very important for the circular economy. If we are using the electric vehicle we can reduce emission savings and protect the environment. Electric vehicles can contribute to energy efficiency, reducing carbon emissions unfortunately, despite everything, the development of the electric vehicle market in Lithuania remains relatively slow. Electric vehicles are more expensive than traditional vehicles, there is a lack of the necessary infrastructure, and consumers do not have enough information on the benefits of green cars. The main purpose of this article is to research electric vehicles market in Lithuania. The methods of research include scientific literature analysis, statistics data comparative analysis. Electrical vehicle market in Lithuania is growing. From 2017 until 2020 M $_{1}$ class electric cars was purchased $35 \%$. At the same period the market of new electric car increased $50 \%$, used electric vehicle increased only $27 \%$.
\end{abstract}

Keywords: consumer, electric vehicles, promoting measures.

\section{Introduction}

Electric cars market is very important due to the European Union (EU) Strategy. This is because electric vehicles are a quick way to meet two challenges at once: to achieve national gas reduction targets and to solve the problem of high pollution in urban centres.

According to F. Brans et al. $35 \%$ of vehicles will be electric, so it is important to create alternative to classical transport that is more expensive from economic, environmental and health security point of views (Bran, Popescu, \& Diaconu, 2018).

Electric vehicles use energy more efficiently than fossil fuel vehicles, so replacing cars with electric vehicles could contribute to improving energy efficiency.

The potential of renewable energy sources to power electric vehicles has associated co-benefits in terms of reduced air pollution. However, the extent to which this may occur varies greatly by country. 
The study aim to find out Lithuanian people willingness to use $\mathrm{M}_{1}$ class electric cars, by using statistic data analysis from 2017 until 2020.

In order to achieve a purpose these objectives have been identified:

1. After literature review to identify the incentive factors and incentive measures for affecting purchase of electric vehicles.

2. To analyse and to compare results of the research.

The methods of research include scientific literature analysis, statistics data by evaluating the relative and dynamic chain sizes of the structure.

\section{Literature Review}

Recently growing population generate the increase number of vehicles in cities and consumption of fuel. We have new regulations that encourage development of infrastructure and sale for electric vehicles.

The main required activities for green vehicles market are management of green infrastructure net; the regulation that facilitate companies, public entities and population to have access to vehicles but also to the infrastructure; management of financing procedures (Bran et al., 2018).

Following this F. Farkas (2018) identified the key factors for increasing electric cars. There are important financially supporting, the charging network. The most important are range of available services and wait-in-line time (Farkas, Gál, Tóth, Szabó, Bíró, Véha, \& Molnár, 2018).

Consumers consistently rank vehicle purchase price, fuel economy, and reliability as attributes of primary importance in motivating their purchasing decisions (Krause, Lane, Carley, \& Graham, 2016).

Cost, recharge time are all important factors in increasing the appeal of the electric car but reductions in purchase price have the largest effect size. Consumers should be better informed about the variety of fuel-efficient vehicles (Peters, Haan, \& Scholz, 2015).

Several motivational factors have been identified to explain purchasing decisions about electric vehicles. Research suggests that government incentives, environmental concerns, and general interest in technological innovations are influential in driving vehicle-purchasing decisions (Dumortier, Siddiki, Carley, Cisney, Krause, Lane, \& Graham, 2015).

Nowadays there is a significant number of news and programme attends with the expansion of the electric vehicles that enjoy governmental priority (Farkas et al., 2018)

In order to encourage the development of electric vehicles, governments implement incentives policy instruments that increase the competitiveness and popularity of these measures for consumer choice (Mačiulis, Konstantinavičiūtè, Pilinkienè, \& Stundžienè, 2019). 
Today the problem of integrating the environmental and economic must be important for cities (Bran et al., 2018).

If government and cities are thinking about electric cars integration and population, they must give some financial incentives. Local authorities is very important for consumers. They can communicate with electric cars buyers, consulting them about electric cars advantages (Mačiulis et al., 2018).

Due to customer's buying the electric cars and this is more advantages than disadvantages for the cities. However, at the same time the management of cities must think about new challenges (Farkas et al., 2018).

Traditional cars are cheaper in comparison to electric vehicles. Electric cars buyers need more information about advantages of these cars. In some countries infrastructure is not so good too. The above-mentioned must be important to think about the implementation of financial and non-financial electric cars promotion measures (Mačiulis et al., 2018).

Both federal and state policy makers are considering whether to retain, enlarge, or reduce the tax credits and rebates that are offered to consumers who purchase an electric vehicle (Krause et al., 2016).

Implementation of national policy may help to consumers' to buy more electric vehicle. Reducing $\mathrm{CO} 2$ emissions from the city will not reduce CO2 emissions globally if industry simply moves elsewhere. The energy policies is very important and must be adopted in the transport policies (Sabel et. al., 2016).

Green cars market, however environmentally imperative, economically profitable and socially essential it might be, simply cannot be developed using sheer (political) power of will (Bran et al., 2018).

It must be acknowledged that the sale of clean cars can be influenced not only by active direct measures taken by the government, but also by many other factors, such as fuel prices, car model prices, population income. Some of these indicators can also be influenced by the government, which also leads to demand for electric vehicles (Mačiulis et al., 2019).

The theoretical model illustrates that the environmental benefits of an electric vehicle arises from reduced damages relative to the gasoline vehicle it replaces. Electric vehicle subsidies may be justified due to innovation spillovers. If innovation is a public good, then markets may provide too little innovation. However, it is worth noting that electric vehicle subsidies are a "demand pull" innovation policy and hence are subject to all the limitations of demand pull policies (Holland, Mansur, Muller, \& Yates, 2016).

The grants, rebates, home charging equipment will increased the need for electric cars (Windisch, 2013).

The development of the market for electric cars brings benefits related to human health and wellbeing, air quality and the environment, as well as economic growth (Sabel et al., 2016; Mačiulis et al., 2019). 
In addition, electric vehicles have become simply a convenient alternative to conventional vehicles, and developments in this market are driving changing consumer needs and expectations. The advantages of electric vehicles are free parking and opportunity to the access to bus lanes (Mačiulis et al., 2018; Mačiulis et al., 2019).

\section{Methodology}

The study took place - the study was conducted in 2020 based on statistics data from 2017 until 2020. The State Enterprise REGITRA is given the statistics data information.

The State Enterprise REGITRA started its activities on 7 January 2000 after its registration with the Ministry of Economy of the Republic of Lithuania. The enterprise keeps the register of vehicles of the Republic of Lithuania (The State Enterprise REGITRA, 2020)

The study analysed the statistics registered in from 2017 until 2020 to $\mathrm{M}_{1}$ passenger vehicles with a power source for electricity only. Based on the data of the register, the age group of natural persons, amount of income, sex, etc. are not disclosed. Therefore, these criteria were not consider in the assessment.

Class $\mathrm{M}_{1}$ means a vehicle for the caring for passengers, compose not more than eight passenger seats and one driver's seat (passenger car) (The Seimas of the Republic of Lithuania).

The actual electric vehicle uses electricity as the only power source, which is charged from the electricity grid into the electric vehicle battery. A plug-in hybrid electric vehicle is a hybrid vehicle, which has an electric engine, battery and a regular internal combustion engine. Such vehicles are more universal, however, their maintenance is very complicated and pricey. Benefits, e.g. parking the vehicle in a city free of charge, also this does not apply to hybrid vehicles (The Environmental Project Management Agency, 2020).

The relative sizes of a structure indicate the distribution of the whole under consideration, especially the relative weight of the parts of that whole in the whole. The relative sizes of a structure are calculated by dividing the number of units in the whole by the number of units in the whole. The relative values of the structure are expressed in parts (coefficients) or percentages of the unit. The relative sizes of the structure are calculated to the extent that the components (parts of the whole) make up the whole in question. Adding the coefficients or percentages of the individual parts gives 1 or $100 \%$, respectively (Gabrevičienè, 2012). 
Proceedings of the International Scientific Conference. Volume VI, May $28^{\text {th }}-29^{\text {th }}$, 2021. 255-263

$$
S \text { structure }=\frac{\text { the part of the whole }\left(A_{i}\right)}{\text { the whole } \mathrm{A}}
$$

where S structure - the relative size of the structure,

$A_{i}$ - the part of the whole,

$A$ - the whole,

The relative magnitudes of the dynamics indicate the change in the phenomenon under consideration over time. They are obtained by comparing the data of the present (reporting) period of the same object with the data of the previous period. With data from the same phenomenon for more than two periods, baseline and chain ratios can be calculated. When calculating the chain dynamics, the denominator of the indicator changes, i.e. the data of each subsequent period are compared with the data of the preceding period (Gabrevičienè, 2012).

$$
S \text { dynamic chain }=\frac{q_{n}}{q_{n-1}}
$$

where $\quad S$ dynamic chain - the chain dynamics the relative magnitude, $q_{n}$ - current period data (subsequent), $q_{n-1}$ - data of the

\section{Research Results}

As reported by the statistical data from 2017 until 2020, a comparative analysis is performed on the number of registered from 2017 until $2020 \mathrm{M}_{1}$ class passenger cars with a power source only for natural persons.

The study findings were systematized and analysed via MS Excel. The analysis of the results used descriptive statistics (percentage distribution).

The aim was to find out the distribution of fuel types and the extent of electric cars. Thus, the trends in fuel distribution in from 2017 until 2020 are assessed. It can be stated that according to all analysed fuels, electric vehicles account for $0.31 \%$ and petrol/electricity for $3.53 \%$. Comparing the type of fuel in from 2017 until 2020 - the number of electric vehicles $3.75 \%$ more in 2018 than in 2017, and in $20194.61 \%$ more than in 2018. $26.70 \%$ in 2020 more than in 2019.

The arithmetic were achieved in the following order:

1. The values for each individual fuel for 2017-2020 shall be summed to give the total number for the selected fuel type for the selected period. General fuel vehicles are summed in a similar way.

2. The relevant fuel (diesel, petrol, etc.) and the sum of that period are then calculated according to formula 1 for the part of the total (A). Total (A) all total fuels and amount for the period 2017-2020. 
Table 1-show $\mathrm{M}_{1}$ class vehicles in Lithuania from 2017 until 2020. These vehicles was catalogued for the first time in Lithuania.

Table 1 M Class Vehicles from 2017 until 2020 in Lithuania (REGITRA, 2020)

\begin{tabular}{|c|c|c|c|c|c|c|c|c|}
\hline Year & \multicolumn{2}{|c|}{2017} & \multicolumn{2}{c|}{$\mathbf{2 0 1 8}$} & \multicolumn{2}{c|}{$\mathbf{2 0 1 9}$} & \multicolumn{2}{c|}{2020} \\
\hline $\begin{array}{c}\text { Type of } \\
\text { fuel }\end{array}$ & $\begin{array}{c}\text { New } \\
\text { cars }\end{array}$ & $\begin{array}{c}\text { Used } \\
\text { cars }\end{array}$ & New cars & $\begin{array}{c}\text { Used } \\
\text { cars }\end{array}$ & New cars & $\begin{array}{c}\text { Used } \\
\text { cars }\end{array}$ & New cars & $\begin{array}{c}\text { Used } \\
\text { cars }\end{array}$ \\
\hline Diesel & 9004 & 116094 & 7756 & 124645 & 8229 & 129506 & 6946 & 93047 \\
\hline Petrol & 16034 & 33886 & 21924 & 39346 & 34433 & 51703 & 24453 & 39830 \\
\hline $\begin{array}{c}\text { Petrol / } \\
\text { Gaseous }\end{array}$ & 14 & 3481 & 14 & 3377 & 9 & 3958 & 81 & 2702 \\
\hline $\begin{array}{c}\text { Petrol / } \\
\text { Electricity }\end{array}$ & 536 & 2511 & 2342 & 3320 & 3131 & 4331 & 7950 & 4142 \\
\hline Electricity & 47 & 277 & 143 & 273 & 162 & 367 & 453 & 731 \\
\hline Total & 25635 & 156249 & 32179 & 170961 & 45964 & 189865 & 39883 & 140452 \\
\hline
\end{tabular}

Source: The State Enterprise REGITRA

Thus, it is obvious that in from 2017 until 2020, the number of electric vehicles will increase and will continue to increase. As reported by the information provided for the site of the Ministry of Transport and Communications on 2021-01-01, 2496 electric vehicles heightened by 106 compared to 2020. Thus, the general trend is increasing every year and this controlled by the measures to promote electric vehicles.

In assessing the trends of registered 2017-2020 $\mathrm{M}_{1}$ class passenger cars with power source only electricity, a dynamic chain relative size was applied. Thus, according to formula 2, 2017 was q0, 2018 was q1, 2019 was q2, 2020 was q3. Further comparison of the number of new / used vehicles in 2017 with 2018. Later comparison of the number of new / used vehicles in 2018 with the results obtained in 2019, etc.

Number of registered from 2017 until $2020 \mathrm{M}_{1}$ class passenger cars with power source only in from 2017 until 2020. After the tendency of new and used electric vehicles acquisition in Lithuania in from 2017 until 2020, it can be seen that in 2017-2018 new electric vehicles increased by $12.61 \%$ and used ones decreased by $0.25 \%$. The statistical data show that during 2018 -2019 new electric cars increased $2.50 \%$. Number of used electric cars in the same period decreased $14.88 \%$. Assessing the year 2019-2020, it can be seen that the number of both new and used electric cars increased, new ones by as much as $32.46 \%$ and used ones by as much as $18.27 \%$. Such an increment in the number of used cars may have been determined by the incentives for the purchase of electric cars and / or the attitude of the population towards environmentally friendly vehicles. 
According to a survey which was done by one of Lithuanian bank in 2020 years 43 percent. Lithuanians tend to give preference to cars with a hybrid engine. A third (33\%) would like to buy a car with a petrol engine, and two years ago, diesel cars, which were in the third place on the list two years ago, were replaced by electric cars: a quarter would choose them, $26 \%$. respondents. Even $40 \%$ respondents consider the car's environmental friendliness to be a very important criterion, and such a population has increased by 10 percentage points (Mickus, 2020).

Based on the information provided on the website of the (The Ministry of Transport and Communications of the Republic of Lithuania, 2021) it can be seen that the need to purchase electric vehicles is further increasing based on the number of applications received. 2021-01-06 Promotion of the purchase of electric vehicles for natural persons 543 applications received; number of new electric cars - 142; number of used electric cars - 401; added for car destruction 98; reserved / disbursed from the Climate Change Program - 1.48 mln. EUR (out of 5 million).

The number of new electric vehicles at the beginning of January 2021 was one less compared to the number of new electric vehicles in 2018 because of the full year. The number of used electric vehicles is 34 higher compared to the total results at the end of 2019.

The study results shows that it can be stated that the need for the purchase of M1 class cars with the power source only electricity by natural persons is increasing and the incentive programs determine this.

\section{Conclusions}

1. Due to significant changes in the world, there is an increasing focus on electric vehicles. The increase in the need to purchase electric vehicles is determined by the infrastructure, charging time. Other key links between economic aspects such as car model, prices, household income, fuel economy, reliability, subsidy and tax cuts. The financial incentives is important for electric cars using increasing.

2. The study results present Lithuanian M1 class cars information. The electric cars are not as popular as diesel of petrol fuel cars but the statistics data from 2017 until 2020 show that Lithuanian M1 class the electrical car purchase is growing up. At this period was purchased $35 \%$. The statistical data analysis shows that new electric cars increased $50 \%$, used electric vehicle increased $27 \%$. The growing was due to Lithuanian government incentives for buying electric vehicles. 


\section{References}

Bran, F., Popescu, M-L., Diaconu, A. (2018). Development Perspectives of Green Car Market. Economics, Management, and Financial Markets 13(3), 154-161.

Dumortier, J., Siddiki, S., Carley, S., Cisney, J., Krause, R. M., Lane, B. W., Rupp, J. A., \& Graham, J. D. (2015). Effects of providing total cost of ownership information on consumers' intent to purchase a hybrid or plug-in electric vehicle. Transportation Research Part A: Policy \& Practice, 72, 71-86. DOI: https://doi.org/10.1016/j.tra. 2014.12.005

Farkas, F., Gál, J., Tóth, I. T., Szabó, I. P., Bíró, I., Véha, A., \& Molnár, T. (2018). Monitoring the Set up and Use of Electric Cars and Charging Points in Szeged. Acta Technica Corviniensis - Bulletin of Engineering, 11(3), 79-83.

Gabrevičienè, A. (2012). Bendroji statistika. Marijampolè: Piko valanda.

Holland, S. P., Mansur, E. T., Muller, N. Z., \& Yates, A. J. (2016). Are There Environmental Benefits from Driving Electric Vehicles? The Importance of Local Factors. American Economic Review, 106(12), 3700-3729. DOI: 10.1257/aer.20150897

Krause, R. M., Lane, B. W., Carley, S., \& Graham, J. D. (2016). Assessing demand by urban consumers for plug-in electric vehicles under future cost and technological scenarios. International Journal of Sustainable Transportation, 10(8), 742-751. DOI: https://doi.org/10.1080/15568318.2016.1148213

Mačiulis P., Konstantinavičiūtè, I., Pilinkienè, V. (2018). Assessment of Electric Vehicles Promotion Measures at the National and Local Administrative Levels. Inzinerine Ekonomika-Engineering Economics, 29(4), 434-445. DOI: https://doi.org/10.5755/ j01.ee.29.4.19960

Mačiulis, P., Konstantinavičiūtė, I., Pilinkienė2, V., \& Stundžienė, A. (2019). Elektromobilių panaudojimo plètrą skatinančių priemonių efektyvumo vertinimo modelis. Energetika (0579-2983), 65(4), 205-221.

Mickus, S. (2020). Experts: electric road transport - faster than we imagine. Retrieved from: https://www.seb.lt/infobankas/automobilis/ekspertai-elektra-varomas-transportaskeliuose-greiciau-nei-isivaizduojame

Perdiguero, J., Jimenez, J., L. (2012). Policy Options for the Promotion of Electric Vehicles: a Review. Working Paper. Research Institute of Applied Economics. Retrieved from: http://diposit.ub.edu/dspace/bitstream/2445/58406/1/IR12-008_Perdiguero.pdf

Peters, A., de Haan, P., \& Scholz, R. (2015). Understanding Car-Buying Behavior: Psychological Determinants of Energy Efficiency and Practical Implications. International Journal of Sustainable Transportation, 9(1), 59-72. DOI: https://doi.org/ 10.1080/15568318.2012.732672

Sabel, C. E., Hiscock, R., Asikainen, A., Bi, J., Depledge, M., van den Elshout, S., Friedrich, R., Huang, G., Hurley, F., Jantunen, M., Karakitsios, S. P., Keuken, M., Kingham, S., Kontoroupis, P., Kuenzli, N., Liu, M., Martuzzi, M., Morton, K., Mudu, P., \& Willers, S. (2016). Public health impacts of city policies to reduce climate change: findings from the URGENCHE EU-China project. Environmental Health: A Global Access Science Source, 15 Suppl 1, 25. DOI http://dx.doi.org/10.1186/s12940-016-0097-0

The Environmental Project Management Agency (EPMA). (2020). Business support for electric vehicles. Retrieved from: https://www.apva.lt/nuo-gruodzio-14-d-paramaverslui-naujiems-krovininiams-elektromobiliams-isigyti/ 
The Ministry of Transport and Communications of the Republic of Lithuania (Ministry). (2021). Electric cars in Lithuania. Retrieved from: https://sumin.Irv.lt/lt/veiklossritys/kita-veikla/pletra-ir-inovacijos/kita-veikla/pletra-ir-inovacijos/elektromobiliuskaicius-lietuvoje

The Seimas of the Republic of Lithuania (LRS). (2008). Director's order. Requirements for classes of categories of motor vehicles and their trailers. Retrieved from: https://eseimas.Irs.lt/rs/legalact/TAD/TAIS.332547/format/ISO_PDF/

The State Enterprise REGITRA. (2020). Activities. Retrieved from: https://regitra.lt/en/thestate-enterprise/activities

The State Enterprise REGITRA (REGITRA). (2020). Statistics data. Retrieved from: https://www.regitra.lt/lt/atviri-duomenys/?datayear=2017\&dataquery=

Windisch, E. (2013). Driving electric? A Financial Analysis of Electric Vehicle Policies in France. Statistical Finance. Ecole des Ponts ParisTech. Retrieved from: https://tel.archives-ouvertes.fr/tel-00957749/document 